\title{
LMNA Gene Product
}

National Cancer Institute

\section{Source}

National Cancer Institute. LMNA Gene Product. NCI Thesaurus. Code C136975.

A protein encoded by the LMNA gene. 